Témoigner Témoigner. Entre histoire et mémoire

Getuigen Revue pluridisciplinaire de la Fondation Auschwitz

$123 \mid 2016$

Traduire le témoignage

\title{
Élise Fontenaille-N’Diaye. Blue book
}

Paris, Calmann-Lévy, 2015

Jean-Pierre Pisetta

Traducteur : Gorik de Henau

\section{(2) OpenEdition}

\section{Journals}

Édition électronique

URL : https://journals.openedition.org/temoigner/5550

DOI : 10.4000/temoigner.5550

ISSN : 2506-6390

Éditeur :

Éditions du Centre d'études et de documentation Mémoire d'Auschwitz, Éditions Kimé

Édition imprimée

Date de publication : 1 octobre 2016

Pagination : 193-194

ISBN : 987 2-9600926-4-6

ISSN : 2031-4183

Référence électronique

Jean-Pierre Pisetta, «Élise Fontenaille-N'Diaye. Blue book», Témoigner. Entre histoire et mémoire [Online], 123 | 2016, Online op 02 novembre 2021, geraadpleegd op 04 novembre 2021. URL: http:// journals.openedition.org/temoigner/5550; DOI: https://doi.org/10.4000/temoigner.5550

Ce document a été généré automatiquement le 4 novembre 2021.

Tous droits réservés 


\title{
Élise Fontenaille-N’Diaye. Blue book
}

Paris, Calmann-Lévy, 2015

\author{
Jean-Pierre Pisetta
}

Traduction : Gorik de Henau

\section{RÉFÉRENCE}

Élise Fontenaille-N’Diaye. Blue book. Paris, Calmann-Lévy, 2015, 209 p.

De Joden wordt vaak verweten - al hebben ze de verwijten niet afgewacht om er zich bitter over te berouwen - dat ze zich met have en goed aan de Duitse autoriteiten overleverden, dat ze geen vermoeden hadden van de barbarij waartoe die in staat waren, dat ze vertrouwden op de wellevendheid van een cultureel hoogstaand volk.

2 Als diezelfde autoriteiten de wreedheden niet hadden verborgen die ze dertig jaar eerder in West-Afrika hadden begaan, dan hadden de Joden met een aan zekerheid grenzende waarschijnlijkheid de zaak minder vertrouwd, hadden ze meer voorzorgen genomen en waren ze in elk geval naar de kampen vertrokken zonder zich illusies te maken over het lot dat hun daar wachtte. Maar meer dan een eeuw na de gebeurtenissen waarover Elise Fontenaille-N'Diaye het in haar Blue Book heeft - en waar je vanaf nu niet meer omheen kunt - heeft Duitsland nog altijd zijn ongelijk niet bekend, toch niet op het hoogste staatsniveau, in wat geldt als de eerste 'volkerenmoord'.

Alles begon eind negentiende eeuw. West-Afrika of Zuidwest-Afrika was een gebied dat in de ogen van het Westen aan niemand toebehoorde. Het werd immers alleen bewoond door herdersvolkeren, al waren die al decennia lang gekerstend door missionarissen uit de Kaap. De Herero's, binnen die herders de grootste bevolkingsgroep, telden ongeveer 80000 zielen, de Nama's (ook Hottentotten genoemd) circa 20 000. In die tijd vestigden er zich Duitse handelaren en opdat ze onbelemmerd handel zouden kunnen drijven en aan landbouw doen, stuurden de autoriteiten van hun vaderland - die onder leiding van keizer Wilhelm I hun keus op die gronden hadden laten vallen - in 1885 een zekere Heinrich Göring, de toekomstige vader van de bekendere en beruchte Hermann. Hij 
moest er niet alleen voor het beheer instaan, maar ook en vooral zoveel mogelijk land opkopen van de herders, die er angstvallig op toezagen. Dat gebeurde al snel. Het verbouwen en handel drijven namen een aanvang, en daarmee ook het machtsmisbruik.

De kolonisering ging gepaard met spanningen en twintig jaar later, in 1904, gebeurde het onherstelbare toen een honderdtal boeren door opstandige Herero's werden afgemaakt. Keizer Wilhem II, kleinzoon van de eerste kolonisator, liet zien uit wat voor hout de Duitsers zijn gesneden wanneer een 'minderwaardig ras' het op hen heeft gemunt. Eugen Fischer, de mentor van Joseph Mengele, ontwikkelde op dat ogenblik zijn beruchte theorieën, die hij weldra in de kolonie zou toetsen. Vijf maanden later vertrokken 15000 tot de tanden gewapende soldaten richting Zuidwest-Afrika, wat buiten proportie was gezien de rudimentaire wapens van de opstandelingen.

Wat volgde wordt tot in ondraaglijke details beschreven in het boek van Elise Fontenaille-N'Diaye. Het lijkt wel of je herleest hoe aan het begin van de Tweede Wereldoorlog de Joden in Oost-Europa werden afgeslacht. Na vier jaar bloedbaden, verkrachtingen, slagen en dwangarbeid in onder meer zes concentratiekampen werden de Herero's bijna helemaal van de kaart geveegd (nauwelijks één vijfde van de bevolking overleefde het), en ook bijna de helft van de Hottentotten (die pas helemaal op het einde in opstand waren gekomen). Om te vieren dat hij dertig jaar aan het bewind was, was de keizer zo welwillend de genocidale repressie stop te zetten en de concentratiekampen te sluiten.

6 In 1917, nadat de Engelsen de Duitse autoriteiten van het grondgebied hadden verdreven, stelde majoor Thomas O'Reilly een vernietigend rapport op over de volkerenmoord, dat hij in 1918 aan zijn superieuren overhandigde. Elise FontenailleN'Diaye geeft het de titel Blue Book mee, zonder enige uitleg over het waarom van die kleuraanduiding. Deze tekst, maar ook andere waarin het gedrag van de Duitsers werd aangeklaagd, meer bepaald aangaande gebieden die ze tijdens de Eerste Wereldoorlog in Europa hadden bezet, moest ertoe leiden dat Duitsland verzaakte aan elke koloniale aanspraak.

7 Het onderzoek naar de Duitse gewelddaden in Afrika moest echter snel worden afgebroken, omdat de Duitsers naar verluidt bezig waren met een White Book over de wandaden waaraan de andere westerlingen zich in hun eigen kolonies schuldig maakten. Zo geraakte de volkerenmoord op de Herero's en de Hottentotten bijna meteen in de vergetelheid en tijdens de jaren twintig werd het bevel gegeven om alle exemplaren van het Blue Book te vernietigen - al duikelde Elise Fontenaille-N'Diaye er toch een op in Pretoria. Thomas O'Reilly stierf vreemd genoeg op 36-jarige leeftijd, nauwelijks een paar maanden nadat hij het onderzoek had afgerond. De kleine Göring kon in alle rust zijn ding doen, er zou in de kranten geen gewag worden gemaakt van wat zijn papa aan de andere kant van de wereld in gang had gezet. En Eugen Fischer kon op allerwetenschappelijkste wijze dokter Mengele opleiden, waarbij hij steunde op zijn conclusies over levensbedreigende rassenvermenging, die hij uit het toekomstige Namibië had meegebracht.

Wat de nazaten van de Herero's en de Hottentotten betreft, die speuren nog altijd de horizon af in de hoop dat daar, na het schip dat hun de bloeddorstige generaal Lothar von Trotha met zijn Vernichtungsbefehl (bevel tot uitroeiing) bracht, een kanselier zal verschijnen voorzien van een officiële erkenning van de misdrijven van zijn voorouders - een erkenning die er sinds de publicatie van dit boek eindelijk lijkt aan te komen. 
9 Het Blue Book van Elise Fontenaille-N'Diaye, dat de ondertitel 'récit' (relaas) meekreeg, laat zich feitelijk veeleer als verhaal dan als essay lezen, waardoor in ieders bereik komt wat tot dusver alleen een handvol ingewijden wisten. Aanzienlijke fragmenten uit het Blue Book van Thomas O'Reilly zijn, in het Frans vertaald, terug te vinden in het tweede deel van het boek. 